\title{
Nekton populations, long-term wetland loss, and the effect of recent habitat restoration in Galveston Bay, Texas, USA
}

\author{
Lawrence P. Rozas ${ }^{1 *}$, Thomas J. Minello ${ }^{2}$, Roger J. Zimmerman ${ }^{2}$, Philip Caldwell ${ }^{2}$ \\ ${ }^{1}$ NOAA Fisheries Service, Southeast Fisheries Science Center, Estuarine Habitats and Coastal Fisheries Center, \\ 646 Cajundome Boulevard, Room 175, Lafayette, Louisiana 70506, USA \\ ${ }^{2}$ Galveston Laboratory, 4700 Avenue U, Galveston, Texas 77551-5997, USA
}

\begin{abstract}
We used data from 1984 samples taken approximately monthly over 11 yr (1982 to 1992) with a $2.6 \mathrm{~m}^{2}$ drop sampler to quantify and compare nekton densities in Spartina alterniflora marsh edge and over adjacent shallow nonvegetated bottom (SNB) in Carancahua Cove, Galveston Bay estuary, Texas, USA. We also used a Geographic Information System (GIS), aerial photography, and population models to track changes in wetland area and trends in fishery populations over time. Decapod crustaceans were less speciose than fishes (35 vs. 60 species) in our samples, but this taxonomic group accounted for most (91\%) of the animals we collected. Annual variability in animal abundance was high. Most species peaked in abundance during spring or fall, and were absent or occurred at low densities during winter. Mean densities of all abundant decapod crustaceans and several abundant fishes in our study were significantly greater in marsh vegetation than over SNB. Based on our GIS analysis, we estimated that $61 \%$ of the wetlands in the study area were converted to open water between 1982 and 1995; marsh edge (marsh within $1 \mathrm{~m}$ of the shoreline) was reduced by $70 \%$ during the same period. Our fishery models showed that brown shrimp Farfantepenaeus aztecus, white shrimp Litopenaeus setiferus, and blue crab Callinectes sapidus populations also declined substantially during this period as the area of wetlands and marsh edge was reduced. A marsh-terracing project in 1999 replaced some open water with marsh, and our models show that populations of these fishery species rebounded in response to this recent restoration effort.
\end{abstract}

KEY WORDS: Fishery species · Gulf of Mexico · Temporal distribution · Habitat selection · Nursery areas $\cdot$ Penaeid shrimps $\cdot$ Tidal marsh $\cdot$ Habitat change

\section{INTRODUCTION}

Coastal wetland loss is a major source of environmental change in the northern Gulf of Mexico. These estuarine wetlands support important coastal fisheries (Houde \& Rutherford 1993, Zimmerman et al. 2000), and decreased fishery landings are expected if the current rate of wetland loss continues (Browder et al. 1989, Zimmerman et al. 1991). Extensive loss of tidal wetlands has occurred in the Galveston Bay estuary of Texas, USA, due to subsidence (caused by subsurface fluid withdrawal), development, erosion, and various other mechanisms (White \& Tremblay 1995, White et al. 2004). Between the 1950s and 1989, approximately 10700 ha of marsh in this estuary were converted to open water (White et al. 1993). Galveston Island lost $32 \%$ of its estuarine marsh from the 1950 s to 2002 (White et al. 2004). Since the 1990s, numerous projects have been implemented to return some of these openwater areas to marsh (Rozas et al. 2005), but these efforts have restored only a fraction of what was lost.

Galveston Bay has also been the focus of numerous studies that examined habitat use patterns by fishery species and other natant organisms (see Minello 1999 and references listed therein). One of these investigations was a multi-year sampling program initiated by 
the NOAA Fisheries Service Galveston Laboratory in 1982 to monitor nekton densities in shallow estuarine habitats of Galveston Island State Park (GISP). The first year of this study was described in Zimmerman et al. (1984) and Zimmerman \& Minello (1984). The longterm database generated from this sampling program provided an opportunity to examine population patterns and look for potential relationships between changes in wetland area and population trends in the system.

The overall objective of our study was to examine long-term patterns of nekton habitat use, habitat change, and trends in fishery populations. We analyzed data collected over an 11 yr period (1982 to 1992) from Carancahua Cove in the western portion of the GISP to describe the composition and seasonal abundance of nekton (fishes and decapod crustaceans) in nearshore habitat and to compare densities of dominant species of nekton (as a measure of habitat quality) between emergent marsh vegetation and shallow nonvegetated bottom (SNB). We also quantified the change in salt marsh area in Carancahua Cove from aerial images taken between 1982 and 2005, determined the extent of seagrass cover across the study area in 2005, and documented changes in habitat and modeled populations of selected fishery species from 1982 to 2005.

\section{MATERIALS AND METHODS}

Study area. Our study area was located within Carancahua Cove in the GISP $\left(29^{\circ} 12^{\prime} \mathrm{N}, 94^{\circ} 58^{\prime} \mathrm{W}\right)$ on the upper Texas coast along the margin of West Bay, an arm of the Galveston Bay estuary (Fig. 1). Intertidal vegetation in the study area was primarily Spartina alterniflora Loisel. The West Bay system is microtidal. Tides within the study area are predominantly diurnal, and the mean tidal range is approximately $0.3 \mathrm{~m}$ (Orlando et al. 1991).

Nekton sampling. Nekton was quantitatively sampled with a drop sampler using the procedure described by Zimmerman et al. (1984). We chose a drop sampler for this study because the catch efficiency of this enclosure device does not appear to vary substantially with habitat characteristics typical of shallow estuarine areas, and, unlike many other gear, it is effective in dense emergent vegetation (Rozas \& Minello 1997). We employed a $1.8 \mathrm{~m}$ diameter cylinder that was dropped from a boom attached to a shallow-draft boat. The cylinder was positioned over a sample site, released from the boom, and it rapidly entrapped organisms within a $2.6 \mathrm{~m}^{2}$ sample area.

We collected a total of 992 pairs of samples between 1982 and 1992 within 2 distinct habitat types, Spartina alterniflora edge (marsh 1 to $2 \mathrm{~m}$ from shoreline) and the adjacent SNB. Sample sites were selected haphazardly near the marsh shoreline, and sites within a pair were located as close to each other as practically possible. We collected samples only when both habitat types were inundated and available to aquatic organisms. Each year, we planned to collect 8 samples per habitat type each month, but, in some years, low water levels (controlled by weather conditions) precluded the collection of samples during some months. We sampled each habitat type between 76 (in 1982) and 96 (in 1986 to 1988,1990 to 1992) times annually over this $11 \mathrm{yr}$ period. The mean monthly sample size (number of samples) for each habitat type ranged between 4 (January) and 12 (April). We collected all samples during the day, and sample sites were all $<1 \mathrm{~m}$ deep.

We measured environmental variables (water temperature, dissolved oxygen, salinity, turbidity, and water depth) within the enclosed sample area before removing nekton (Zimmerman et al. 1984). Most nekton

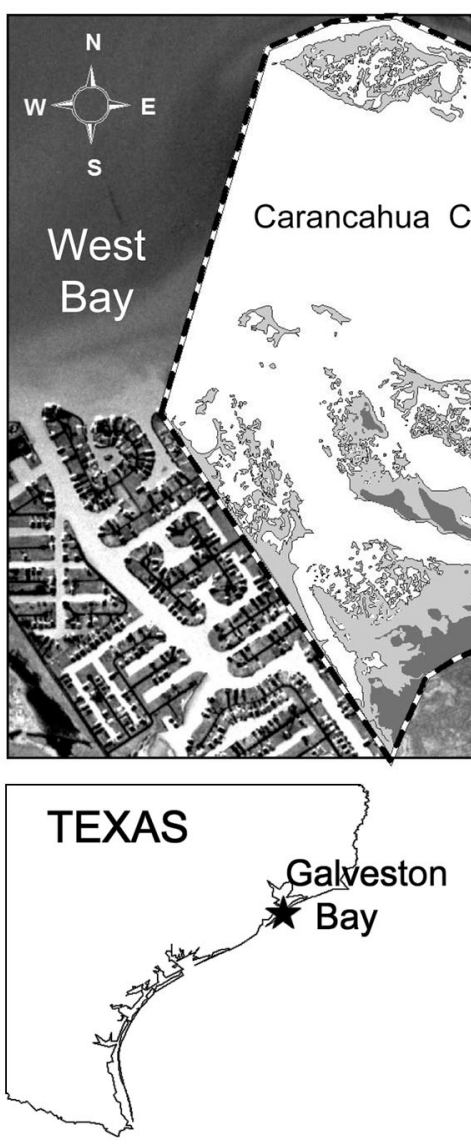


was then removed from the drop sampler using dip nets and by filtering the water pumped out of the enclosure through a $1 \mathrm{~mm}$ mesh net. When the sampler was completely drained, any animals remaining on the bottom were collected by hand. Samples were preserved in formalin with Rose Bengal stain and returned to the laboratory for processing.

In the laboratory, the samples were sorted, and animals were identified to the lowest feasible taxon level. Penaeid shrimps were measured in samples from 1982 to 1992 to the nearest millimeter in total length (TL); other crustaceans and fishes were measured (carapace width for crabs and TL for other taxa) from 1985 to 1992 and assigned to $10 \mathrm{~mm}$ ( $5 \mathrm{~mm}$ for blue crab) size categories.

We examined annual variability in abundance and recruitment to these shallow water habitats for selected species. We distinguished between 2 life stages (recent recruits and older juveniles) based on size. Size-frequency distribution curves were plotted using all the available size data for each species, and recent recruits were identified as equal to or smaller than the size at which these curves peaked and began to decline. Recruits were assumed to be the following sizes: blue crab $\leq 10 \mathrm{~mm}$; brown shrimp and white shrimp $\leq 20 \mathrm{~mm}$; Atlantic croaker, gulf menhaden, and red drum $\leq 26 \mathrm{~mm}$; and spotted seatrout and spot $\leq 36 \mathrm{~mm}$. Larger individuals were assumed to be older juveniles. The portion of the annual mean density assigned to each life stage for any given year was based on the proportion of recruits and older juveniles identified from the samples taken during that year.

GIS classification, habitat analysis, and fishery population projections. We calculated the areas of vegetation and water at different distances from the marsh edge for each of $7 \mathrm{yr}(1982,1985,1987,1990,1992$, 1995, and 2005) when aerial photography of the study area was available using ArcView 3.2a (ESRI) and a process similar to that described by Minello \& Rozas (2002). Base maps for each year were constructed in a Geographic Information System (GIS) from aerial images (see Appendix 1; available as Supplementary Material online at www.int-res.com/articles/suppl/ m344p119_app.pdf). The boundary for the study area was set to include all nekton sampling sites and the regularly flooded wetland areas and adjacent SNB in Carancahua Cove that support fishery populations (Fig. 1). Although absent in earlier years, patches of seagrass were observed in the GISP in 1999 (King \& Sheridan 2006). Most of the seagrass occurred in areas of the GISP east of Carancahua Cove, but we documented small amounts of seagrass cover in Carancahua Cove from the 2005 aerial image.

We generated habitat layers in vector format for each year. First, we digitized the areas of water, vegetation, and other land cover in each scene using an on-screen digitization procedure. We then converted from vector to raster format and classified the vegetation and water areas in each scene into different categories based on distance to the nearest marsh shoreline (e.g. 0 to 1,1 to $2, \ldots 24$ to 25 , and $>25 \mathrm{~m}$ ) using ArcView Spatial Analyst. We calculated the overall areal coverage of each distance-to-edge category within the water and marsh areas for each scene. Finally, for each year, we applied modeled densities for each distance-to-edge category using Microsoft Excel 2000 to estimate nekton populations for the entire study area.

This modeling approach (Rozas et al. 2005) predicts densities and population size within a marsh complex based on the mean density within marsh edge vegetation. We estimated fishery populations of brown shrimp, white shrimp, and blue crab using 2 different measurements of this mean density in the marsh edge. The first approach used 1 overall mean density for each species, and populations were estimated for the years 1982, 1985, 1987, 1990, 1992, 1995, and 2005. These mean densities were derived from a large dataset of values from throughout lower Galveston Bay (Rozas et al. 2005). Changes in these modeled populations were entirely dependent upon the amount of marsh vegetation and the spatial configuration of the vegetation within Carancahua Cove. The second modeling approach was restricted to 1982, 1985, 1987, 1990, and 1992 when both nekton density data and aerial imagery were available for the study area. In this analysis, population estimates were based on the GIS analysis and the mean density (ind. $\mathrm{m}^{-2}$ ) of nekton in marsh edge habitat for each particular year $(1982,1985,1987,1990$, and 1992), respectively, as follows: brown shrimp = $24.8,20.5,7.7,15.6$, and 11.5; white shrimp $=27.0,5.5$, $5.8,14.4$, and 2.7 ; and blue crab $=7.8,8.7,7.8,6.1$, and 5.4. In both approaches, mean densities were determined using sample data from months when each species was abundant in the estuary (i.e. brown shrimp = April to September, white shrimp $=$ June to November, blue crab = April to November).

Although our GIS analysis was useful for tracking marsh-water change in the study area, image source, scale, film type and processing, and image rectification may limit such analyses of aerial photography. Rectification presented the greatest challenge in our study because the open water portion of the study area lacked identifiable reference points. Terrestrial reference points could be established along roads and buildings, but we could not use the same terrestrial points on every image due to anthropological changes to the landscape over time and because the altitude of image acquisition differed among photographs. Given these limitations, we achieved only a first-order rectification of the images. 
Statistical analyses. We used paired $t$-tests (StatView Version 4.5, Abacus Concepts) to examine differences in densities of abundant organisms and environmental characteristics (mean dissolved oxygen, salinity, water temperature, and turbidity) between habitat types. We considered alpha levels of 0.05 to be significant in all results, but we also assessed significance after adjusting alpha levels for $t$-test results using the sequential Bonferroni method described by Rice (1989), which buffers against error introduced by making multiple comparisons (i.e. testing a hypothesis for numerous species or dependent variables) with the same sample set. We present significance results in this manner because some readers may be interested in only 1 or 2 statistical tests (e.g. 1 species), and the unadjusted significance values are appropriate for such comparisons.

We computed summary statistics (mean, SE, range) on the size data for fishes and crustaceans separately. We estimated the size of each animal assigned to a 5 or $10 \mathrm{~mm}$ size category as one-half the size range to which it was assigned.

\section{RESULTS}

\section{Animal data}

We identified 60 species of fishes and 35 species of decapod crustaceans from 1984 samples taken over the 11 yr (1982 to 1992) study period (Table 1, see also Appendix 2, available at www.int-res.com/articles/suppl/ m344p119_app.pdf). Most animals could be identified to species, but 31 specimens were identified only to genus (i.e. Eucinostomus, Scorpaena, Callianassa; Appendix 2). Grass shrimps collected from 1982 to 1985 were all assumed to be daggerblade grass shrimp Palaemonetes pugio, but these shrimps were identified to species after 1985. Over the next 7 yr (1986 to 1992), daggerblade grass shrimp, marsh grass shrimp $P$. vulgaris, and brackish grass shrimp $P$. intermedius accounted for 93.0, 4.2, and $2.8 \%$, respectively, of the grass shrimps in our samples.

Sampling effort was not evenly distributed over this 11 yr period. Fewer samples (152) were collected in

Table 1. Overall mean densities (ind. $\mathrm{m}^{-2}$ ) of commonly collected fishes ( $>0.5 \%$ of total fishes) and crustaceans ( $>0.6 \%$ total crustaceans) in 2 habitat types (Spartina alterniflora [S. a.] marsh edge and shallow nonvegetated bottom[SNB]) at Galveston Island State Park. Each mean is estimated from 992 drop samples. Total number and relative abundance (number of individuals/total number of animals collected $\times 100$ ) are also given. Results (p-values) are given for paired $t$-tests comparing mean densities of taxa between the 2 habitat types. ${ }^{*}$ : probability value for the paired $t$-test was significant after alpha was adjusted, as described by Rice (1989) at the $5 \%$ level

\begin{tabular}{|c|c|c|c|c|c|c|c|c|}
\hline \multirow[t]{2}{*}{ Common name } & \multirow[t]{2}{*}{ Scientific name } & \multirow{2}{*}{$\begin{array}{c}\text { Total } \\
\text { no. }\end{array}$} & \multirow{2}{*}{$\begin{array}{c}\text { Relative } \\
\text { abundance } \\
(\%)\end{array}$} & \multicolumn{2}{|c|}{ S.a. marsh edge } & \multicolumn{2}{|c|}{ SNB } & \multirow[t]{2}{*}{ p-value } \\
\hline & & & & Mean & SE & Mean & SE & \\
\hline Total fishes & & 20312 & 9.5 & 4.48 & $(0.30)$ & 3.37 & $(0.40)$ & 0.0203 \\
\hline Pinfish & Lagodon rhomboides (Linnaeus, 1766) & 4420 & 2.1 & 1.38 & $(0.11)$ & 0.32 & $(0.05)$ & $0.0001^{*}$ \\
\hline Bay anchovy & Anchoa mitchilli (Valenciennes, 1848) & 3387 & 1.6 & 0.32 & $(0.24)$ & 1.00 & $(0.28)$ & 0.0666 \\
\hline Naked goby & Gobiosoma bosc (Lacepède, 1800) & 3280 & 1.5 & 1.14 & $(0.09)$ & 0.14 & $(0.02)$ & $0.0001^{*}$ \\
\hline Gulf menhaden & Brevoortia patronus Goode, 1878 & 1736 & 0.8 & 0.03 & $(0.01)$ & 0.64 & $(0.26)$ & 0.0191 \\
\hline Inland silverside & Menidia beryllina (Cope, 1867) & 1433 & 0.7 & 0.38 & $(0.07)$ & 0.18 & $(0.04)$ & 0.0105 \\
\hline Spot & Leiostomus xanthurus Lacepède, 1802 & 1315 & 0.6 & 0.05 & $(0.01)$ & 0.45 & $(0.06)$ & $0.0001^{*}$ \\
\hline Blackcheek tonguefish & Symphurus plagiusa (Linnaeus, 1766) & 884 & 0.4 & 0.16 & $(0.02)$ & 0.19 & $(0.02)$ & 0.1585 \\
\hline Spotted seatrout & Cynoscion nebulosus (Cuvier, 1830) & 769 & 0.4 & 0.26 & $(0.02)$ & 0.04 & $(0.01)$ & $0.0001^{*}$ \\
\hline \multirow[t]{2}{*}{ Darter goby } & Ctenogobius boleosoma & & & & & & & \\
\hline & (Jordan and Gilbert, 1882) & 671 & 0.3 & 0.18 & $(0.02)$ & 0.08 & $(0.01)$ & $0.0001^{*}$ \\
\hline Gulf killifish & Fundulus grandis Baird and Girard, 1853 & 380 & 0.2 & 0.15 & $(0.01)$ & 0.00 & $(0.00)$ & $0.0001^{*}$ \\
\hline Atlantic croaker & Micropogonias undulatus (Girard, 1854) & 352 & 0.2 & 0.04 & $(0.01)$ & 0.10 & $(0.02)$ & 0.0133 \\
\hline Striped mullet & Mugil cephalus Linnaeus, 1758 & 212 & 0.1 & 0.05 & $(0.01)$ & 0.03 & $(0.01)$ & 0.0122 \\
\hline Red drum & Sciaenops ocellatus (Linnaeus, 1766) & 194 & 0.1 & 0.04 & $(0.01)$ & 0.04 & $(0.01)$ & 0.7039 \\
\hline Speckled worm eel & Myrophis punctatus Lütken, 1852 & 143 & 0.1 & 0.06 & $(0.02)$ & 0.08 & $(0.02)$ & 0.2219 \\
\hline \multirow[t]{2}{*}{ Southern flounder } & Paralichthys lethostigma & & & & & & & \\
\hline & Jordan and Gilbert, 1884 & 131 & 0.1 & 0.03 & $(0.00)$ & 0.03 & $(0.00)$ & 0.8904 \\
\hline Total crustaceans & & 192670 & 90.5 & 67.87 & $(2.00)$ & 6.87 & $(0.36)$ & $0.0001^{*}$ \\
\hline Daggerblade grass shrimp & Palaemonetes pugio Holthuis, 1949 & 109396 & 51.4 & 41.33 & $(1.59)$ & 1.07 & $(0.22)$ & $0.0001^{*}$ \\
\hline Brown shrimp & Farfantepenaeus aztecus (Ives, 1891) & 33968 & 15.9 & 10.67 & $(0.43)$ & 2.57 & $(0.14)$ & $0.0001^{*}$ \\
\hline White shrimp & Litopenaeus setiferus (Linnaeus, 1767) & 19252 & 9.0 & 5.78 & $(0.51)$ & 1.68 & $(0.18)$ & $0.0001^{*}$ \\
\hline Blue crab & Callinectes sapidus Rathbun, 1896 & 19111 & 9.0 & 6.13 & $(0.26)$ & 1.27 & $(0.05)$ & $0.0001^{*}$ \\
\hline Marsh grass shrimp & Palaemonetes vulgaris (Say, 1818) & 3487 & 1.6 & 1.34 & $(0.20)$ & 0.01 & $(0.00)$ & $0.0001^{*}$ \\
\hline \multirow[t]{2}{*}{ Brackish grass shrimp } & Palaemonetes intermedius & & & & & & & \\
\hline & Holthuis, 1949 & 2354 & 1.1 & 0.88 & $(0.12)$ & 0.03 & $(0.02)$ & $0.0001^{*}$ \\
\hline \multirow[t]{2}{*}{ Pink shrimp } & Farfantepenaeus duorarum & & & & & & & \\
\hline & (Burkenroad, 1939) & 2079 & 1.0 & 0.67 & $(0.08)$ & 0.14 & $(0.03)$ & $0.0001^{*}$ \\
\hline
\end{tabular}


1982 than in any subsequent year; sampling effort was nearly uniform (192 $\mathrm{yr}^{-1}$, except only 176 in 1989) after 1985. Within any year, most samples were taken during March and November, and the fewest samples were collected in January and February (see Appendix 3, available at www.int-res.com/articles/suppl/ m344p119_app.pdf).

Although less speciose than fishes, crustaceans were much more numerous (91\% of all animals) in our samples (Table 1). The mean size of crustaceans in our samples was $24 \mathrm{~mm}(\mathrm{SE}=0.03)$, the range was 3 to $188 \mathrm{~mm}$, and $96 \%$ of the specimens were $<50 \mathrm{~mm}$. Daggerblade grass shrimp, brown shrimp Farfantepenaeus aztecus, white shrimp Litopenaeus setiferus, blue crab Callinectes sapidus, marsh grass shrimp, brackish grass shrimp, and pink shrimp Farfantepenaeus duorarum accounted for $98 \%$ of all the crustaceans we collected (Table 1).

Fishes collected in our samples ranged in size from 3 to $696 \mathrm{~mm}$ TL (mean = $34 \mathrm{~mm}, \mathrm{SE}=0.22$ ), and $98 \%$ of these animals were $<100 \mathrm{~mm}$ TL. Abundant species represented $95 \%$ of all the fishes we collected (Table 1).

Monthly animal densities fluctuated substantially, and the timing of seasonal peaks in abundance varied among species (Fig. 2). Peak abundance for most species occurred in spring (March to May) or fall (September to November). Most species were least abundant in winter (December to February), although daggerblade grass shrimp and blue crab occurred at moderate densities during December (Fig. 2, Appendix 3).

Length of stay in the study area also varied among species (Fig. 2). Some species were abundant for only a short period. For example, pinfish Lagodon rhomboides were abundant in spring, but few individuals were taken after June (Fig. 2, Appendix 3). Few white shrimp were collected before June, and their numbers decreased dramatically after August (Fig. 2, Appendix 3). Other species exhibited an extended period of abundance in the study area. For example, brown shrimp was relatively abundant for 9 mo (March through November; Fig. 2, Appendix 3).

Annual variability in abundance differed greatly among species (Fig. 3). Coefficients of variation (CV) for Atlantic croaker Micropogonias undulatus, red drum Sciaenops ocellatus, gulf menhaden Brevoortia patronus, and white shrimp were 1.52, 1.09, 0.75, and 0.62, respectively. Annual variability was lower $(\mathrm{CVs}=0.23$ to 0.28$)$ for spotted seatrout Cynoscion nebulosus, brown shrimp, and blue crab (Fig. 3). A portion of this year-to-year variability can be attributed to differences in annual recruitment of young into the study area. We compared changes in the annual density of small recruits over our $11 \mathrm{yr}$ record as the basis for examining annual variability in recruitment for 8 species (Fig. 3). Annual variability in recruitment was highest for species such as Atlantic 
croaker $(\mathrm{CV}=1.52)$ and gulf menhaden $(\mathrm{CV}=1.01)$ and was relatively low (CVs $=0.34$ to 0.36 ) for spotted seatrout, brown shrimp, and blue crab (Fig. 3). When we examined the relationship between the annual abundance of recruits and juveniles, there was a significant positive regression only for Atlantic croaker and red drum $(\mathrm{p}<0.003)$.
Most of the numerically dominant species in our study apparently selected marsh sites over SNB (Table 1, Fig. 4). Mean densities of all abundant decapod crustaceans and 7 of the most abundant fishes (pinfish, naked goby, spotted seatrout, inland silverside, darter goby, gulf killifish, and striped mullet) in our study were significantly greater in marsh vegetation than over
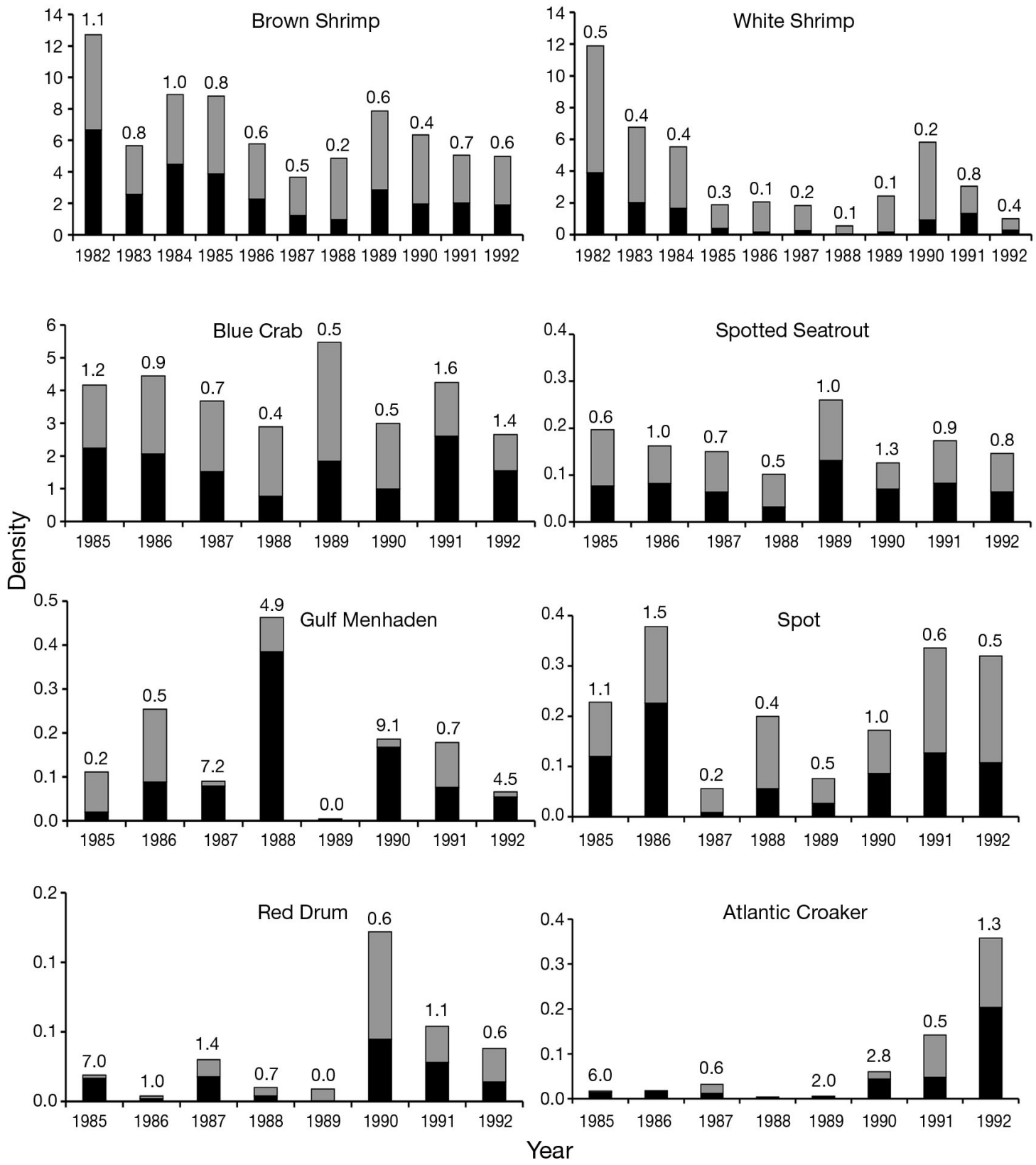

Fig. 3. Variability in mean annual density of selected species segregated by size. Total height of the bars represents the mean density $\left(\mathrm{m}^{-2}\right)$ of all individuals collected in both marsh edge and nonvegetated bottom habitats; proportions of the 2 size classes (recent recruits and older juveniles: black and gray bars, respectively) are shown, and the ratio between recruits and older juveniles is labeled over each column. Recruits were assumed to be the following sizes: blue crab $\leq 10 \mathrm{~mm}$; brown shrimp and white shrimp $\leq 20 \mathrm{~mm}$; Atlantic croaker, gulf menhaden, and red drum $\leq 26 \mathrm{~mm}$; and spotted seatrout and spot $\leq 36 \mathrm{~mm}$. Larger individuals were considered to be older juveniles. Numbers of samples for each year were: $1982=152,1983=168,1984=176$, $1985=160,1986=192,1987=192,1988=192,1989=176,1990=192,1991=192,1992=192$ 
SNB (Table 1). The strength of this selection for vegetation appeared to vary within the year. Brown shrimp, white shrimp, blue crab, and spotted seatrout selected marsh habitat most strongly from late spring through fall (Fig. 4). In contrast, mean densities of gulf menhaden, spot Leiostomus xanthurus and Atlantic croaker were significantly greater over SNB than at marsh sites.

\section{Environmental data}

Environmental conditions differed temporally and followed a natural seasonal pattern within the year (Fig. 5, see also Appendix 4, available at www.int-res.
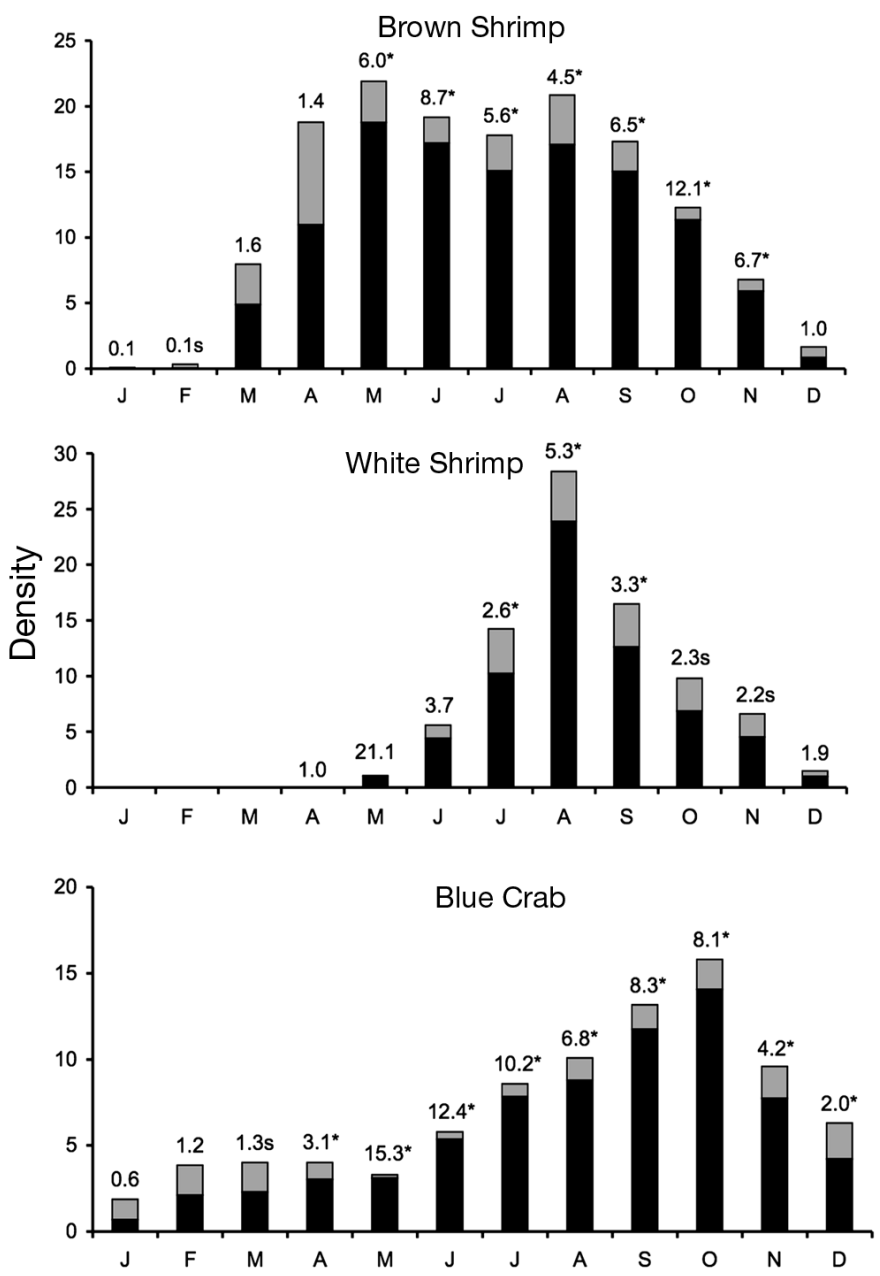

com/articles/suppl/m344p119_app.pdf). Mean water temperature was lowest in February $\left(15.3^{\circ} \mathrm{C}\right)$ and highest in July $\left(30.2^{\circ} \mathrm{C}\right)$. The pattern for salinity was similar; mean salinity was lowest in February (19.8 psu) and peaked in August (29.9 psu). Mean dissolved oxygen concentration was relatively high throughout the year, and, as expected, negatively related to water temperature; the highest mean value $\left(9.5 \mathrm{mg} \mathrm{l}^{-1}\right)$ was observed in January and February and the lowest mean concentration $\left(6.2 \mathrm{mg} \mathrm{l}^{-1}\right)$ occurred in August. Mean turbidity readings (Formazin Turbidity Unit, FTU) in the study area ranged from 10.0 (January) to 34.1 (August). Water depth was highest in May and September and lowest in January (Fig. 5).
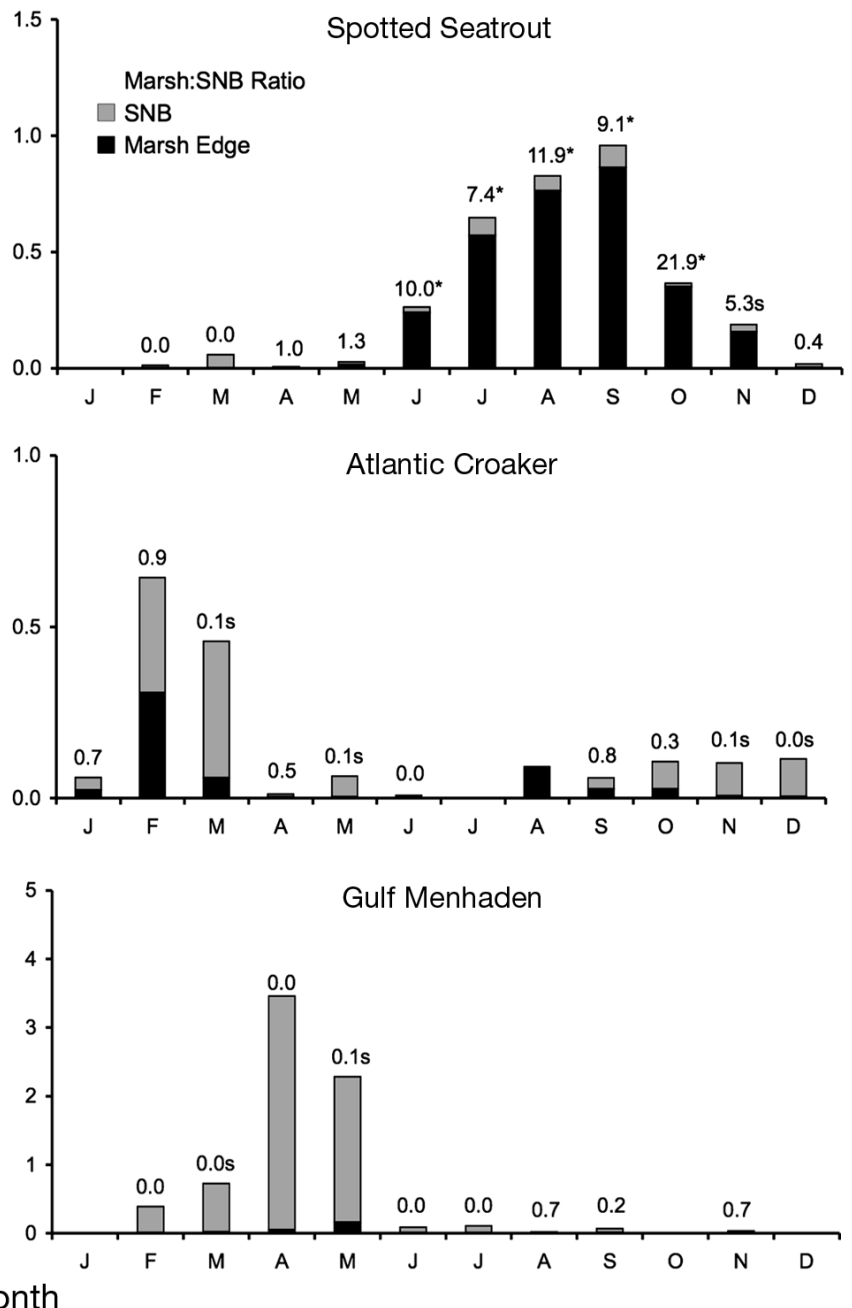

Fig. 4. Distribution of mean monthly densities (ind. $\mathrm{m}^{-2}$ ) between habitat types (Spartina alterniflora marsh edge and shallow nonvegetated bottom [SNB]) for selected abundant species collected in the study area. Height of the black bar represents the mean density within marsh edge, and height of the gray segment represents the density in SNB; thus, the total height of the stacked bar represents the sum of the 2 mean densities. The ratio of densities between habitat types is shown over each column. Significant results of paired $t$-tests examining differences in densities between habitat types each month are depicted by an asterisk to indicate that the probability value was significant at the $5 \%$ level after alpha was adjusted for multiple testing, as described by Rice (1989); s: significance without this adjustment. Means were calculated from the following number of samples per habitat type: January = 32, February = 56, March = 104, April = 92, May = 96, June = 96, July = 80, August = 96, September $=84$, 

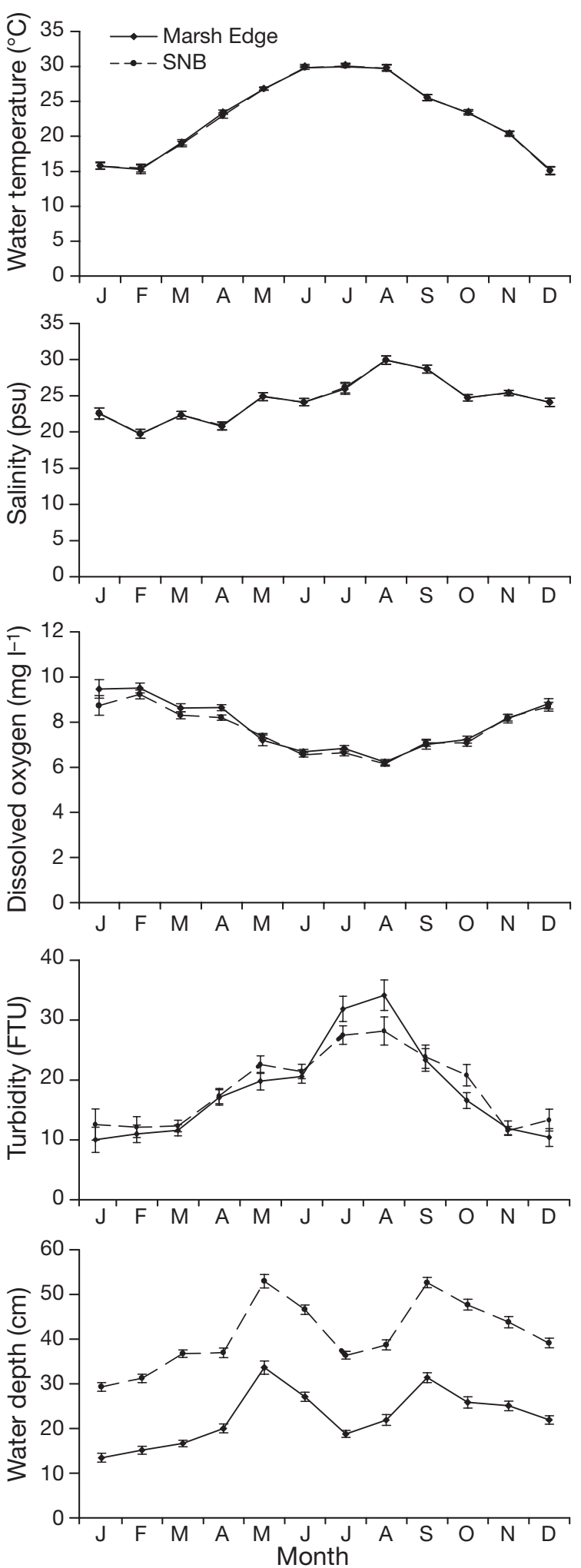

Fig. 5. Monthly mean values of 5 environmental variables measured between 1982 and 1992 in each habitat type (Marsh edge: Spartina alterniflora marsh edge; SNB: shallow nonvegetated bottom) in the study area. Number of samples used to estimate each mean is given in Appendix 4. Error bars $=1$ standard error. FTU: Formazin Turbidity Unit
Although differences in means of most environmental variables between habitat types were small, differences for 3 variables were statistically significant (Fig. 5, Appendix 4). Means of water temperature (23.7 vs. $\left.23.5^{\circ} \mathrm{C}\right)$ and dissolved oxygen concentration ( $7.8 \mathrm{vs}$. $7.6 \mathrm{mg} \mathrm{l}^{-1}$ ) were higher and mean water depth (23 vs. $42 \mathrm{~cm}$ ) was less at marsh than at SNB sites. The small differences in water temperature and dissolved oxygen concentration between habitat types are unlikely to be biologically significant. However, differences in water depth between habitat types were relatively large. In contrast to the other environmental variables we measured in this study, water depth, along with vegetation structure, did likely influence the nekton density patterns we observed. Means of salinity and turbidity were not significantly different between habitat types.

\section{Changes in habitat and fishery populations}

Based on our GIS analysis, a substantial part of the study area converted from wetlands to shallow open water during the course of this study (Table 2, Fig. 6). Emergent marsh decreased in the study area from approximately 47 ha in 1982 to 18 ha in 1995 . The proportion of the study area classified as marsh edge (marsh located within $1 \mathrm{~m}$ of the shoreline) also decreased during this time from a high of $4.2 \%$ (8.7 ha) in 1985 to $1.0 \%$ (2.1 ha) in 1995 (Table 2). Between 1995 and 2005, the area of marsh increased to 30 ha and that of marsh edge to 6 ha (Table 2). The marsh terracing project initiated in 1999 had reversed the trend of continuous marsh loss since 1982.

Our models projected a concomitant decrease in the populations of penaeid shrimps and blue crab within the study area between 1982 and 1995 (Fig. 6). These modeled population estimates were based on composite mean densities in vegetated marsh edge (13.5 brown shrimp $\mathrm{m}^{-2}, 11.3$ white shrimp $\mathrm{m}^{-2}$, and 6.8 blue crabs $\mathrm{m}^{-2}$ ) for polyhaline areas of Galveston Bay, and do not take into account annual fluctuations in abundance. Population estimates decreased for brown shrimp from $>4$ million in 1982 and 1985 to $<2.2$ million in 1995 (46\% reduction), for white shrimp from 3.7 million in 1982 to 1.5 million in 1995 (58\% reduction), and for blue crab from $>3$ million in 1982 and 1985 to 2.1 million in 1995 ( $34 \%$ reduction). By the year 2005, in response to the increase in area of marsh and marsh edge from marsh terracing, our models based on composite mean densities showed that brown shrimp, white shrimp, and blue crab populations increased from 1995 levels to $3.4,2.8$, and 2.7 million, respectively. Model estimates derived from annual mean densities based on samples from our study area were much more variable from year to year, but these popu- 
Table 2. Results of Geographic Information System (GIS) cover classification analyses of 7 aerial images taken between 1982 and 2005. Total area (ha) of the study area that was classified as Spartina alterniflora marsh, marsh edge (S. alterniflora marsh $\leq 1 \mathrm{~m}$ from shore), open water (shallow nonvegetated bottom), and other are shown. The 'other' category contained cover types that could not be classified as either open water or $S$. alterniflora marsh. Percentages of the total area that was marsh, marsh edge, and open water are also given for each year

\begin{tabular}{|cccccccc|}
\hline Year & $\begin{array}{c}\text { S. alterniflora } \\
\text { marsh (ha) }\end{array}$ & $\begin{array}{c}\text { Marsh edge } \\
\text { (ha) }\end{array}$ & $\begin{array}{c}\text { Open water } \\
\text { (ha) }\end{array}$ & $\begin{array}{c}\text { Other } \\
\text { (ha) }\end{array}$ & $\begin{array}{c}\text { Marsh } \\
(\%)\end{array}$ & $\begin{array}{c}\text { Marsh edge } \\
(\%)\end{array}$ & $\begin{array}{c}\text { Open water } \\
(\%)\end{array}$ \\
\hline 1982 & 47.07 & 7.04 & 158.12 & 47.82 & 22.94 & 3.43 & 77.06 \\
1985 & 45.17 & 8.72 & 163.49 & 44.36 & 21.65 & 4.18 & 78.35 \\
1987 & 44.32 & 5.75 & 163.48 & 45.22 & 21.33 & 2.77 & 78.67 \\
1990 & 22.31 & 4.19 & 184.88 & 45.83 & 10.77 & 2.02 & 89.23 \\
1992 & 21.50 & 2.37 & 186.21 & 45.31 & 10.35 & 1.14 & 89.65 \\
1995 & 18.32 & 2.09 & 191.76 & 42.94 & 8.72 & 1.00 & 91.28 \\
2005 & 30.26 & 6.00 & 185.54 & 37.22 & 14.02 & 2.78 & 85.98 \\
\hline
\end{tabular}

lation estimates also generally decreased between 1982 and 1992 (Fig. 6). In these projections, brown shrimp in the study area decreased from 7.4 to $<2$ million ( $74 \%$ reduction), white shrimp from almost 9 to $<0.5$ million (95\% reduction), and blue crab from 3.5 to 1.7 million (52\% reduction).

In 2005, approximately $2661 \mathrm{~m}^{2}$ of the study area shown in Fig. 1 was occupied by seagrass. We did not include this habitat type in our population modeling because it has only recently been recorded as present in GISP, and seagrass beds cover a relatively small area of Carancahua Cove (King \& Sheridan 2006).

\section{DISCUSSION}

Most of the species commonly collected in our study area showed a consistent pattern of habitat use. With the onset of tidal flooding, the young of most fishery species and many estuarine residents moved onto the marsh surface from nearby shallow subtidal areas. During low-water periods, these natant organisms (with the exception of some marsh residents) returned to subtidal areas until the next high-water event. Other studies have looked for such a pattern and reported similar results (Zimmerman \& Minello 1984, Kneib \& Wagner 1994, Minello et al. 1994, Kneib \& Knowlton 1995, Rozas \& Minello 1998, Minello 1999, Rozas \& Zimmerman 2000). This association between nekton and marsh vegetation was strongest in late spring through fall, coinciding with seasonally high water levels in the estuary when the marsh surface would be most accessible for aquatic organisms (Zimmerman \& Minello 1984).

We observed distinct seasonal patterns of abundance that were quite consistent from year

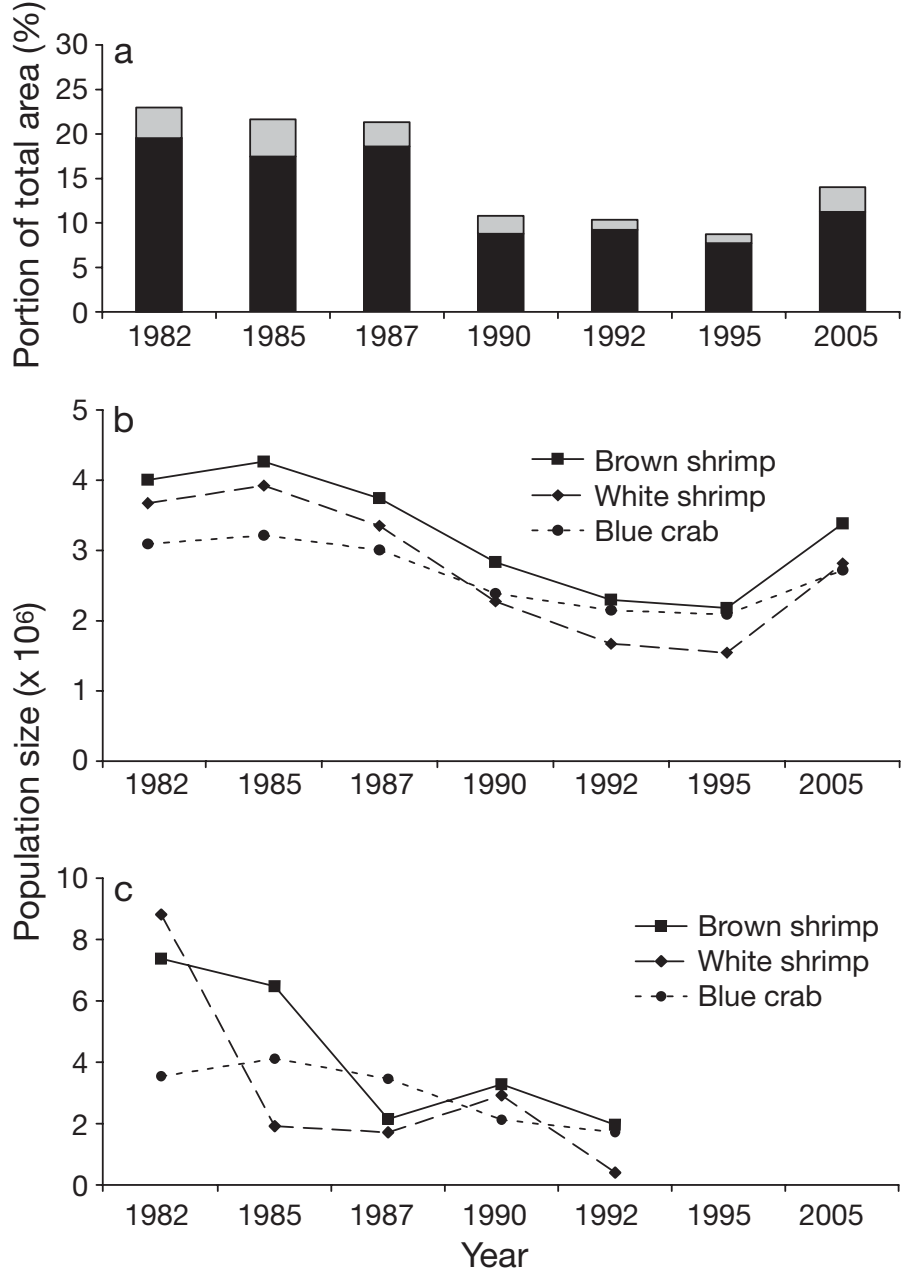

Fig. 6. Habitat change and fishery population trends in the study area between 1982 and 2005. (a) Changes in the percentages of total marsh area (height of bar) and marsh edge (marsh within $1 \mathrm{~m}$ of the shoreline shown as gray shading) in the study area. (b) Model projections of brown shrimp, white shrimp, and blue crab populations in the study area based on habitat change data and using the same mean nekton densities for each year. (c) Population change between 1982 and 1992 based on the same habitat data, but using different mean nekton densities determined from data collected each year in the study area. Note different scales on the $y$-axes 
to year. Although the young of fishery species were present in the study area throughout the year, the abundance of most species peaked either in spring (brown shrimp, gulf menhaden, spot, striped mullet Mugil cephalus, southern flounder Paralichthys lethostigma) or fall (blue crab, spotted seatrout, pink shrimp, red drum). White shrimp and Atlantic croaker were exceptions. Juvenile white shrimp were most numerous in August, but also abundant in July and September, whereas young Atlantic croaker were most abundant in February. Similar seasonal patterns have been reported for other locations in the northern Gulf of Mexico (King 1971, Rogers \& Herke 1985, Rakocinski et al. 1992, Livingston 1997, Akin et al. 2003). These patterns are consistent with what is known about the spawning seasons of these species in the northern Gulf of Mexico and the seasonal abundance of their young (larvae and post-larvae) in gulf waters and estuarine passes (Baxter \& Renfro 1967, King 1971, Ditty 1986, Ditty et al. 1988, Rabalais et al. 1995). As some time is required for these young animals to reach estuarine nursery areas, their peak abundance in the estuary is delayed by up to several weeks from their peak occurrence in gulf waters. For example, larval gulf menhaden are most numerous from January to March in the northern Gulf of Mexico (Shaw et al. 1985, Ditty 1986), while small juveniles are most abundant in lower Galveston Bay during April. Atlantic croaker and spot larvae are most abundant in gulf waters from October to January and December and January, respectively (Ditty et al. 1988); small juveniles of these 2 species reach peak abundance in lower Galveston Bay during February and March, respectively.

Annual variability in the abundance of estuarine populations is generally high (Rothschild 1986, Fogarty et al. 1991, Livingston 1997, Rose 2000), and this characteristic was typified by several taxa in our study. Four species (gulf menhaden, Atlantic croaker, red drum, and white shrimp) in our study showed at least a 20 -fold difference between their highest and lowest mean annual densities. For red drum, this variability may be partially an artifact of our sampling frequency and a relatively narrow recruitment period for this species (Stunz et al. 2002), but most other species examined had extended recruitment periods throughout the year (Fig. 4). The variability in year-to-year densities in our study was higher than that reported by Allen \& Barker (1990) for larval fishes sampled over a $3 \mathrm{yr}$ period in a South Carolina estuary. In their study, winter-spawned taxa had the highest annual variability, and Allen \& Barker (1990) attributed this high variability to annual fluctuations in freshwater inflow and salinity in the estuary. Atlantic croaker and gulf menhaden, which had the highest annual variability in our study, also spawn in winter, and Atlantic croaker was abundant during years (1990 to 1992) with relatively low mean salinities in the months (February and March) when this species reached peak abundance. Gulf menhaden, in contrast, was most abundant in 1982/1983 and 1988, and we did not observe low mean monthly salinities during these years in April and May when menhaden recruitment peaked in the study area.

The abundance of the earliest life stages of transient species (organisms that spawn in the gulf and whose young use estuaries as nursery areas; Beck et al. 2001) is likely to be controlled more by factors outside the estuary than by local environmental conditions within estuarine nursery areas (Hurst et al. 2004). Local environmental conditions affect growth rates and survival of these organisms once they settle as new recruits within the estuary. For example, extended periods of low water would force small juveniles out of emergent vegetation and into nonvegetated subtidal areas where higher predation would increase mortality rates (Minello \& Zimmerman 1991, Haas et al. 2004). The abundance of later-stage juveniles should reflect both recruitment strength and the impact of environmental conditions within estuarine nursery areas (Chesney et al. 2000, Rose 2000, Rooper et al. 2004). A strong positive relationship between recruit abundance and juvenile abundance would suggest that recruitment strength is more important than environmental conditions in determining juvenile abundance in the estuary; we only found such relationships for Atlantic croaker and red drum.

Subsurface fluid withdrawal has accelerated subsidence and caused extensive loss of tidal wetlands in the Galveston Bay system; wetland loss rates have been particularly high in nearshore areas along West Galveston Bay, where our study area was located (White \& Tremblay 1995, White et al. 2004). At Virginia Point, located north and across West Bay from our study area, 1470 ha of salt marsh were converted to open water between 1952 and 1989 (White \& Tremblay 1995). From the 1950s to 2002, 1552 ha of marsh were lost on Galveston Island (White et al. 2004). Based on our GIS analyses, the area of wetlands in our study area decreased by approximately 28.8 ha (a reduction of $61 \%$ ) between 1982 and 1995. More importantly for many species, the area of shoreline marsh (marsh edge) was reduced by 5.0 ha (a reduction of $70 \%$ ) over the same period. The area of available marsh edge is important because this habitat type supports high concentrations of penaeid shrimps and blue crab (Zimmerman et al. 1984, Minello et al. 1994, Peterson \& Turner 1994, Cicchetti 1998, Howe et al. 1999, Minello \& Rozas 2002).

Our models showed a concomitant decrease in fishery populations with this reduction in wetland area (and marsh edge). Both the models based on composite 
mean densities and those using annual mean densities measured in Carancahua Cove showed trends of decreasing fishery populations between 1982 and 1992, but these trends were less consistent in the models that used annual mean densities. Annual variation in abundance of the species modeled (brown shrimp, white shrimp, blue crab) obscured population responses due to habitat change in the study area. These year-to-year fluctuations, so typical of fishery populations, often make detection of environmental effects difficult without a large sample size and a long time series of data (Rose 2000, Hurst et al. 2004). There did not appear to be any strong relationship between the amount of marsh remaining in the study area and annual densities observed or the strength of selection for vegetated marsh surfaces.

A recent restoration project that incorporated marsh terracing increased the area of intertidal marsh and marsh edge at the GISP (Rozas et al. 2005). The terracing project increased the marsh area in Carancahua Cove by approximately $65 \%$ according to our comparison of GIS data from the 1995 and 2005 images. More importantly, this comparison showed that marsh edge increased almost 3-fold between the 2 images. Not surprisingly, our models based on composite mean densities also indicated a rebound in populations in 2005 within the study area following marsh restoration. Population estimates (standing crops) of brown shrimp, white shrimp, and blue crab increased by 55, 83, and $30 \%$, respectively, between 1995 and 2005 in response to the increase in marsh area and marsh edge that resulted from the restoration effort.

These population estimates are likely conservative, because seagrass habitat was not considered in our model analyses. Fishery habitat in the GISP was enhanced when seagrasses recently colonized the area (King \& Sheridan 2006). Halodule wrightii Aschers. and Halophila engelmanni Aschers. were first observed in 1999, and seagrass cover has increased substantially in eastern areas of the GISP. In our Carancahua Cove study area, seagrass increased to $>2500 \mathrm{~m}^{2}$ by 2005 . Although the area currently occupied by these seagrasses is relatively small, seagrass cover is expanding in and around the park, and this habitat type supports relatively high densities of fishery species (Thomas et al. 1990, Minello 1999, King \& Sheridan 2006). These expanding seagrass beds, and ongoing marsh restoration efforts, should at least partially compensate for historical losses of tidal wetlands.

Acknowledgements. This research was conducted through the NOAA Fisheries Service, Southeast Fisheries Science Center by personnel from the Fishery Ecology Branch (FEB) located at the Galveston Laboratory in Texas and the Estuarine Habitats and Coastal Fisheries Center in Lafayette, Louisiana. The assistance of everyone in the FEB was essen- tial for the successful completion of this project. In particular, we thank T. Baumer, F. R. Burditt, Marie Pattillo, J. Davis, M. Daniels, Q. Forrest, T. Kihle, G. McMahan, Mark Pattillo, C. O'Brien, and M. Van for helping collect and process samples. We acknowledge the U.S. Department of the Interior, U.S. Fish and Wildlife Service, and NOAA Fisheries Service for funding this project. The findings and conclusions in this paper are those of the authors and do not necessarily represent the views of the NOAA Fisheries Service.

\section{LITERATURE CITED}

Akin S, Winemiller KO, Gelwick FP (2003) Seasonal and spatial variations in fish and macrocrustacean assemblage structure in Mad Island Marsh estuary, Texas. Estuar Coast Shelf Sci 57:269-282

Allen DM, Barker DL (1990) Interannual variations in larval fish recruitment to estuarine epibenthic habitats. Mar Ecol Prog Ser 63:113-125

Baxter KN, Renfro WC (1967) Seasonal occurrence and size distribution of postlarval brown and white shrimp near Galveston, Texas, with notes on species identification. Fish Bull (Wash DC) 66:149-158

Beck MW, Heck KL, Able KW, Childers DL and 9 others (2001) The identification, conservation, and management of estuarine and marine nurseries for fish and invertebrates. BioScience 51:633-641

Browder JA, May LN Jr, Rosenthal A, Gosselink JG, Baumann RH (1989) Modeling future trends in wetland loss and brown shrimp production in Louisiana using thematic mapper imagery. Remote Sens Environ 28:45-59

Chesney EJ, Baltz DM, Thomas RG (2000) Louisiana estuarine and coastal fisheries and habitats: perspectives from a fish's eye view. Ecol Appl 10:350-366

Cicchetti G (1998) Habitat use, secondary production, and trophic export by salt marsh nekton in shallow water. $\mathrm{PhD}$ dissertation, The College of William and Mary, Williamsburg

Ditty JG (1986) Ichthyoplankton in neritic waters of the northern Gulf of Mexico off Louisiana: composition, relative abundance, and seasonality. Fish Bull (Wash DC) 84: 935-946

Ditty JG, Zieske GG, Shaw RF (1988) Seasonality and depth distribution of larval fishes in the northern Gulf of Mexico above latitude $26^{\circ} 00^{\prime} \mathrm{N}$. Fish Bull (Wash DC) 86:811-823

Fogarty MJ, Sissenwine MP, Cohen EB (1991) Recruitment variability and the dynamics of exploited marine populations. Trends Ecol Evol 6:241-246

Haas HL, Rose KA, Fry B, Minello TJ, Rozas LP (2004) Shrimp on the edge: linking habitat to survival using an individual-based simulation model. Ecol Appl 14:1232-1247

Houde ED, Rutherford ES (1993) Recent trends in estuarine fisheries: predictions of fish production and yield. Estuaries 16:161-176

Howe JC, Wallace RK, Rikard FS (1999) Habitat utilization by postlarval and juvenile penaeid shrimps in Mobile Bay, Alabama. Estuaries 22:971-979

Hurst TP, McKnown KA, Conover DO (2004) Interannual and long term variation in the nearshore fish community of the mesohaline Hudson River estuary. Estuaries 27:659-669

King BD III (1971) Study of migratory patterns of fish and shellfish through a natural pass. Technical Series No. 9, Texas Parks and Wildlife Department, Austin

King SP, Sheridan P (2006) Nekton of new seagrass habitats colonizing a subsided salt marsh in Galveston Bay, Texas. Estuar Coast 29:286-296 
Kneib RT, Knowlton MK (1995) Stage-structured interactions between seasonal and permanent residents of an estuarine nekton community. Oecologica 103:425-434

Kneib RT, Wagner SL (1994) Nekton use of vegetated marsh habitats at different stages of tidal inundation. Mar Ecol Prog Ser 106:227-238

Livingston RJ (1997) Trophic response of estuarine fishes to long-term changes in river runoff. Bull Mar Sci 60: 984-1004

Minello TJ (1999) Nekton densities in shallow estuarine habitats of Texas and Louisiana and the identification of essential fish habitat. In: Benaka L (ed) Fish habitat: essential fish habitat and habitat rehabilitation. Am Fish Soc Symp 22:43-75

Minello TJ, Rozas LP (2002) Nekton in Gulf Coast wetlands: fine-scale distributions, landscape patterns, and restoration implications. Ecol Appl 12:441-455

Minello TJ, Zimmerman RJ (1991) The role of estuarine habitats in regulating growth and survival of juvenile penaeid shrimp. In: DeLoach P, Dougherty WJ, Davidson MA (eds) Frontiers in shrimp research. Elsevier, Amsterdam, p 1-16

Minello TJ, Zimmerman RJ, Medina R (1994) The importance of edge for natant macrofauna in a created salt marsh. Wetlands 14:184-198

Orlando SP Jr, Rozas LP, Ward GH, Klein CJ (1991) Analysis of salinity structure and stability for Texas estuaries. Strategic Assessments Branch, NOS/NOAA, Rockville

Peterson GW, Turner RE (1994) The value of salt marsh edge vs interior as a habitat for fish and decapod crustaceans in a Louisiana tidal marsh. Estuaries 17:235-262

Rabalais NN, Burditt FR Jr, Coen LD, Cole BE and 8 others (1995) Settlement of Callinectes sapidus megalopae on artificial collectors in four Gulf of Mexico estuaries. Bull Mar Sci 57:855-876

Rakocinski CF, Baltz DM, Fleeger JW (1992) Correspondence between environmental gradients and the community structure of marsh-edge fishes in a Louisiana estuary. Mar Ecol Prog Ser 80:135-148

Rice WR (1989) Analyzing tables of statistical tests. Evolution 43:223-225

Rogers BD, Herke WH (1985) Estuarine-dependent fish and crustacean movements and weir management. In: Bryan CF, Zwank PJ, Chabreck RH (eds) Proceedings of the 4th coastal marsh and estuary management symposium. Louisiana State University Agricultural Center, Baton Rouge, p 201-219

Rooper CN, Gunderson DR, Armstrong DA (2004) Application of the concentration hypothesis to English sole in nurseries and potential contribution to coastal fisheries. Estuaries 27:102-111

Rose KA (2000) Why are quantitative relationships between environmental quality and fish populations so elusive? Ecol Appl 10:367-385

Rothschild BJ (1986) Dynamics of marine fish populations. Harvard University Press, Cambridge, MA

Editorial responsibility: Otto Kinne (Editor-in-Chief), Oldendorf/Luhe, Germany
Rozas LP, Minello TJ (1997) Estimating densities of small fishes and decapod crustaceans in shallow estuarine habitats: a review of sampling design with focus on gear selection. Estuaries 20:199-213

Rozas LP, Minello TJ (1998) Nekton use of salt marsh, seagrass, and nonvegetated habitats in a South Texas (USA) estuary. Bull Mar Sci 63:481-501

Rozas LP, Zimmerman RJ (2000) Small-scale patterns of nekton use among marsh and adjacent shallow nonvegetated areas of the Galveston Bay estuary, Texas (USA). Mar Ecol Prog Ser 193:217-239

Rozas LP, Caldwell P, Minello TJ (2005) The fishery value of salt marsh restoration projects. J Coast Res 40:37-50

Shaw RF, Cowan JH Jr, Tillman TL (1985) Distribution and density of Brevoortia patronus (Gulf menhaden) eggs and larvae in the continental shelf waters of western Louisiana. Bull Mar Sci 36:96-103

Stunz GW, Minello TJ, Levin PS (2002) A comparison of early red drum densities among various habitat types in Galveston Bay, Texas. Estuaries 25:76-85

Thomas JL, Zimmerman RJ, Minello TJ (1990) Abundance patterns of juvenile blue crabs (Callinectes sapidus) in nursery habitats of two Texas bays. Bull Mar Sci 46: 115-125

White WA, Tremblay TA (1995) Submergence of wetlands as a result of human-induced subsidence and faulting along the upper Texas gulf coast. J Coast Res 11:788-807

White WA, Tremblay TA, Wermund EG Jr, Handley LR (1993) Trends and status of wetland and aquatic habitats in the Galveston Bay system, Texas. GBNEP-31, Galveston Bay National Estuary Program, Webster

White WA, Tremblay TA, Waldinger RL, Calnan TR (2004) Status and trends of wetland and aquatic habitats on barrier islands, upper Texas Coast, Galveston and Christmas Bays. Final Report to the Texas General Land Office and NOAA, Texas Bureau of Economic Geology, Austin, TX Available online at www.glo.state.tx.us/coastal/statustrends/galveston-christmas/index.html

Zimmerman RJ, Minello TJ (1984) Densities of Penaeus aztecus, Penaeus setiferus, and other natant macrofauna in a Texas salt marsh. Estuaries 7:421-433

Zimmerman RJ, Minello TJ, Zamora G (1984) Selection of vegetated habitat by brown shrimp, Penaeus aztecus, in a Galveston Bay salt marsh. Fish Bull (Wash DC) 82: 325-336

Zimmerman RJ, Minello TJ, Klima EF, Nance JM (1991) Effects of accelerated sea-level rise on coastal secondary production. In: Bolten HS, Magoon OT (eds) Coastal wetlands, coastal zone '91 conference. American Society of Civil Engineers, New York, p 110-124

Zimmerman RJ, Minello TJ, Rozas LP (2000) Salt marsh linkages to productivity of penaeid shrimps and blue crabs in the northern Gulf of Mexico. In: Weinstein MP, Kreeger DA (eds) Concepts and controversies in tidal marsh ecology. Kluwer Academic Publishers, Dordrecht, p 293-314

Submitted: October 13, 2006; Accepted: March 27, 2007

Proofs received from author(s): August 14, 2007 